\title{
Organisational Commitment and Job Satisfaction as Antecedents of Organisational Citizenship Behaviour
}

\author{
Thembi Laura Motaung, Patrick Qena Radebe \\ Vaal University of Technology, Andries Potgieter Boulevard, Vanderbijlpark, South Africa \\ thembim@vut.ac.za, patrick@vut.ac.za
}

\begin{abstract}
Contemporary challenges facing organisations emphasise the need for a calibre of employees who exude organisational citizenship behaviour (OCB) and organisational commitment (OC), including a satisfactory level of job satisfaction (JS). Research is replete with supporting evidence that OCB is triggered by JS and that JS is positively related with OC. Although the relationship between these constructs is considered important, research exploring the relationship between these three constructs in the context of a water utility remains scarce. The primary objective of this research was to examine the impact of OC and JS on OCB at a water utility company in Gauteng. A survey was utilised to elicit responses from 400 sampled participants. A quantitative approach was adopted by which exploratory factor analysis (EFA), correlation and regression analyses were performed to analyse data. Using EFA, three factors of OC were extracted. The results further showed a positive correlation between affective commitment and normative commitment; JS and OCB; and no predictive relationship was observed between continuance commitment and OCB. Based on the findings, it was recommended that JS, OC and OCB should be improved through mechanisms such as job-fit, job enrichment career advancement performance-related pay and mentorship programmes.
\end{abstract}

Keywords: Organisational commitment, job satisfaction, organisational citizenship behaviour

\section{Introduction}

Organisations have been confronted increasingly with dynamic challenges like economic development, rapid technological changes and retention of human capital in a highly competitive business environment (Liu, Li \& Zhao, 2009). In order to achieve a competitive edge and overcome these challenges, organisations depend on their employees' organisational citizenship behaviour (OCB) (Dash \& Pradhan, 2014). First advanced by Bateman and Organ in 1983, OCB generally is considered behaviour of a voluntary nature and a personal choice to help fellow employees and promote an organisation's affective functioning (Organ, 1988, 1997; Organ \& Ryan, 1995; Podsakoff, MacKenzie, Paine \& Bachrach, 2000; Podsakoff, MacKenzie \& Organ, 2006; Lo \& Ramayah, 2009; Alizadeh, Darvishi, Nazari \& Emami, 2012). An array of authors (Organ \& Ryan, 1995; Podsakoff et al., 2000; Nadiri \& Tanova, 2010) hold a consensual view that employees' expression of these behaviours is solely reliant on the organisation's willingness to enhance employees' job satisfaction (JS) and that JS is the antecedent of organisational commitment (OC). In essence, individuals who are satisfied with their jobs are prone to express positive emotions towards and are eager to be involved in and/or identify with their organisation (Lumley, Coetzee \& Tladinyane, 2011). Much of the research to date tends to provide empirical evidence on the associations between JS and OCB, or JS and OC (Suresh \& Venkatammal, 2010; Alizadeh et al., 2012; Rasheed, Jehanzeb \& Rasheed, 2013). Although there is growing evidence that suggests a positive correlation between JS and $\mathrm{OC}$, there is relatively inadequate literature on the correlations pertaining to JS and commitment and their effect on OCB (Lumley et al., 2011; Chinomona, 2012).

The lack of research conducted on the relationship among the aforementioned variables in the context of water utility companies compounds the paucity of research in this area. It is in this context that the objective of this study was to examine the relationship between JS and OC and their effect on OCB in a water utility company in Gauteng. The rationale for this study lies in the consistent challenge of meeting the growing demand for high-quality water, which necessitates the water utility company to maintain high levels of JS and OC among its employees. It also requires the company to realise that the discriminatory withholding of OCB or discretionary gestures may be affected by the levels of JS and OC. Thus, the importance of the study is grounded on the belief that improved levels of JS and OC are the bedrock for the provision of quality water in the Gauteng Province. Improved levels of JS and OC contribute to the occurrence of OCB, which indubitably will add to a better service for the provision of quality water. To address these issues, the paper is structured as follows: the review of the literature on OC, JS and OCB, which enabled the development of research model 
and hypotheses, the description of the research design and methodology, including the presentation of statistical results and findings.

\section{Literature Review}

In this section, the literature was reviewed pertaining to the concepts of OC, JS and OCB.

Organisational Commitment: $O C$ is one organisational component that contributes immensely to the wellbeing of an organisation since it affects how employees feel about an organisation and the extent to which they feel they belong to an organisation, which in turn has an influence on their willingness to advance organisational values and goals (Nematian, Zadeh \& Chehrazi, 2015). Kargar (2012:5017) defines OC as "employees' loyalty to the organisation and a consistent process in which people's cooperation with organisational decisions depicts their attention to the organisation and its success". Meyer and Allen (1991:67), architects of the three-component framework of OC, amplify that OC is an emotional connection an individual forms with the organisation, which necessitates an employee's prolonged stay with an organisation. The authors contend that $\mathrm{OC}$ is a three-dimensional construct comprising of the following variables, namely affective commitment (AC), continuous commitment (CC) and normative commitment. AC is considered an emotional attachment to identification with and involvement in the organisation (Sayğan, 2011:220). Mamman, Kamoche and Bakuwa (2011) affirm that an employee with an effective commitment is attached psychologically to the organisation, developing sentiments of happiness, dependability and cordiality towards the organisation.

CC expresses an employee's willingness to retain membership with the organisation for the reason that the cost of quitting is unbearably greater ( $\mathrm{Ng} \&$ Feldman, 2011). Thus, remaining with the organisation would prove to be a suitable alternative (Neininger, Lehmann-Willenbrock, Kauffeld \& Henschel, 2010). Normative commitment implies that individuals believe they have to continue employment with the organisation on the basis that it is an ethical and acceptable thing to do; it is a moral obligation to stay with the organisation (Falkensburg \& Schyns, 2007). (Güleryüz Güney, Aydin and Asan (2008) opine that a lack of OC could lead to unfavourable outcomes to the organisation, such as employee turnover, absenteeism, tardiness and organisational ineffectiveness. Conversely, Alimohammadi and Neyshabor (2013) consider OC as fundamental to improved organisational performance, job performance, reduced employee turnover, JS and prosocial organisational behaviours (Hettiararchchi \& Jayarathna, 2014). Previous studies have demonstrated sufficiently that OC is a precursor of JS (Anis Khan, \& Humayoun, 2011; Dirani \& Kuchinke, 2011; Adekola, 2012).

Job Satisfaction: JS has dominated research because its prevalence among employees has led to increased productivity in organisations (Çalişkan, 2010; Dugguh \& Dennis, 2014). Gunlu Aksarayli Perçin (2010:695) defines job satisfaction as "the feelings or a general attitude of the employees in relation with their jobs and the job components such as the working environment, working conditions, equitable rewards and communication with colleagues". By implication, employees achieve a positive emotional response or pleasurable emotion of satisfaction when they perceive their jobs to fulfil their important values (Morris \& Venkatesh, 2010). Empirical evidence confirms that employees' attitudes towards various aspects of their jobs and organisation such as pay, supervision, promotion opportunities and relationship with co-workers contribute to the level of employees' satisfaction with their jobs (Chen \& Johantgen, 2010; Aziri, 2011; Altinoz Cakiroglu \& Cop, 2012). Research also alludes that intrinsic aspect like the work itself, responsibility, recognition, achievement, advancement and growth are profound sources of job performance, productivity, occupational stress and burnout (Goetz, Campbell, Broge, Dörfer, Brodowski \& Szecsenyi, 2012; Raza, Akhtar, Husnain \& Aktar, 2015).

In fact, Herzberg (1959) argues that intrinsic factors have a direct bearing on the employees' level of JS. Other individual characteristics, which include age, education, marital status and gender have been found to be key determinants of the level of employees' JS (Khan, Nawaz \& Jan, 2012; Sattar, Nawaz \& Khan, 2012). Kasemsap (2013) contends that employees who are satisfied with their jobs generally exhibit positive attitudes towards their jobs and exert enormous amounts of effort in the execution of their jobs. In addition, JS has been found 
to contribute to enhanced organisational performance (Waqas, Bashir, Sattar, Abdullah, Hussain, Anjum, Ali \& Arshad, 2014). The positive outcomes engendered by JS explain the unshakeable need to keep levels of JS high in the workplace. In fact, Ng and Feldman (2011) have found JS to contribute significantly to employees' enactment of organisational citizenship behaviour.

Organisational Citizenship Behaviour: A classical and widely-acclaimed definition of OCB is that it is "an individual behaviour that is discretionary, not directly or explicitly recognised by the formal reward system and that in the aggregate promotes the effective functioning of the organisation" (Organ, 1988: 4). The salient elements emerging from the definition are that OCB is a voluntary behaviour expressed by employees; it tends to exceed the formal requirements of the job and goes beyond the rules and regulations to ensure the organisation's operations are effective (Tambe \& Shanker, 2014). Empirical studies suggest that OCB comprises five dimensions, namely altruism, conscientiousness, civic virtue, sportsmanship and courtesy (Lo \& Ramayah, 2009, Yahaya, Boon, Ramli, Baharudin, Yahaya, Ismail \& Shariff, 2011; Alizadeh et al., 2012; Ünal, 2013). Ünal (2013) considers altruism to be deliberate actions that help other employees with organisationrelevant tasks in order to execute these tasks timeously. Employees with altruistic behaviour are inclined to impart relevant skills to others to enhance their performance. Various authors concur that conscientiousness includes those behaviours that are aimed at compliance with the rules and regulations of an organisation in pursuance of hurdle-free organisational operations (Singh \& Singh, 2009; Yahaya et al., 2011).

Typical conscientious behaviours encompass giving prior notice of absence from work and complying with instructions (Alizadeh et al., 2012). Civic virtue suggests the eagerness of employees to take part in the political life of the organisation, for example, by attending meetings, making meaningful contributions to performance improvement and performance solutions (Lo \& Ramayah, 2009; Nadiri \& Tanova, 2010; Nielsen, Bachrach, Sundstron \& Halfhill, 2012). Nielsen et al. (2012:675) define sportsmanship as "tolerating lessthan-ideal circumstances or minor workplace distractions and discomforts without complaining". According to Nadiri and Tanova (2010), sportsmanship encourages individuals not to complain about their work environments; rather they should carry out their work tasks with positive attitudes. Lastly, courtesy intimates behaviours that encourage a positive attitude towards other employees; thereby, reducing conflicts in an organisation (Sun, Chow, Chiu \& Pan, 2013). Courtesy allows employees to create an atmosphere that instigates trust, openness, information sharing and respect (Yahaya et al., 2011). Davoudi (2012) opines that OCB has the potential to enhance social cohesion among employees, improve productivity and quality of outputs; hence, it behoves managers to be considerate of factors that contribute to the formation of OCB. There is also sufficient empirical evidence that employees with $O C$ will stay with the organisation and reciprocate to the organisation by engaging in OCB (Ng \& Feldman, 2011).

Conceptual Framework and Hypotheses: The conceptual framework depicted in Figure 1 presumes that normative commitment, affective commitment and continuance commitment are precursors of JS. The model also indicates that JS and the aforementioned dimensions of OC are predictors of OCB. 


\section{Figure 1: Conceptual Framework}

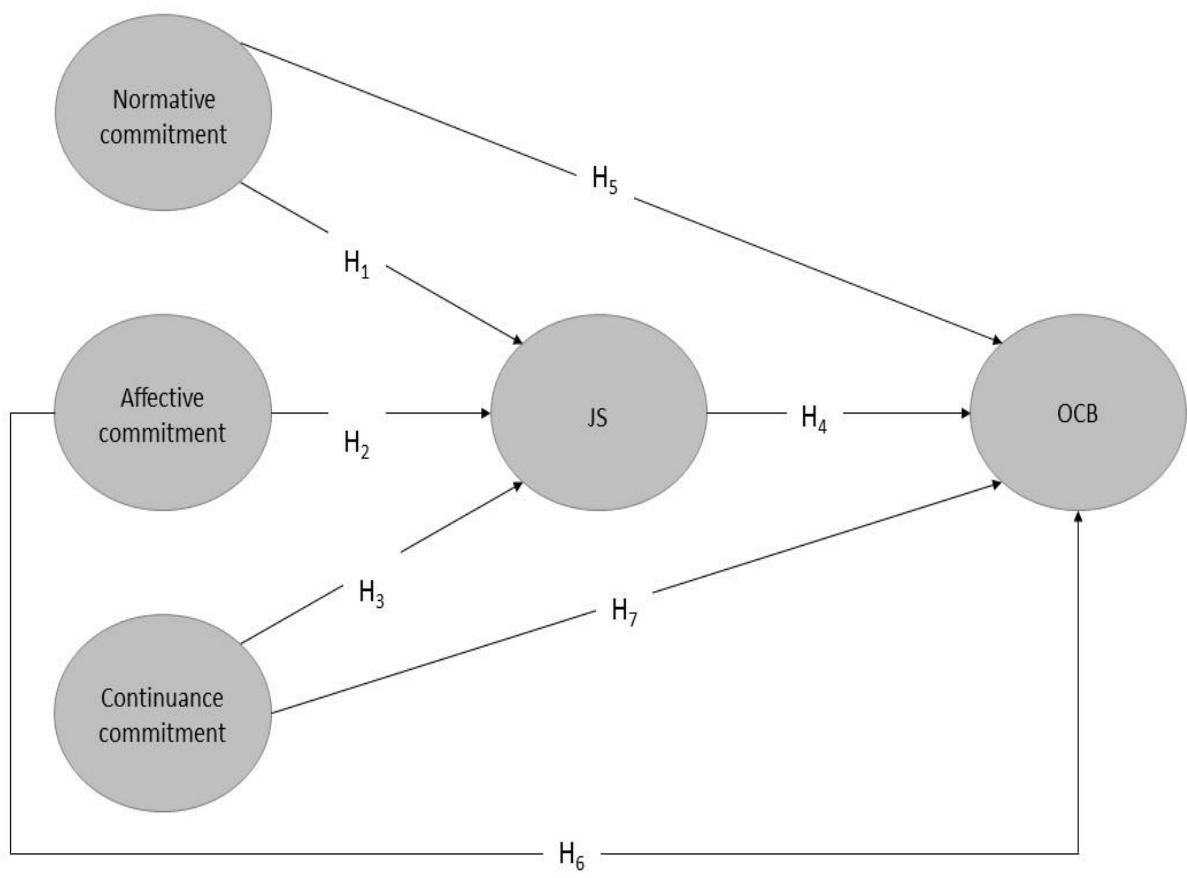

Hypotheses Developed and tested: on the basis of the preceding research studies, these hypotheses were advanced:

H1: A positive link exists between normative commitment and JS.

H2: A positive association exists between affective commitment and JS.

H3: There is a positive relationship between continuance commitment and JS.

H4: Job satisfaction is positively associated with OCB.

H5: Normative commitment and OCB are positive correlates.

H6: There is an existing association between $\mathrm{AC}$ and $\mathrm{OCB}$

H7: CC is positively related with OCB.

\section{Methodology}

A survey using a structured questionnaire was utilised. A quantitative approach was adopted because correlation and regression analyses of variables had to be performed in order to accept or reject hypotheses. To achieve this objective, the following aspects were elaborated upon, namely the sample and sampling method, measuring instrument and collection of data as well as reliability and viability.

Sample and Sampling Method: The study was undertaken in a water utility company situated in Southern Gauteng in South Africa. The targeted sample was personnel from various departments, namely academy, human resources, finance, plants and support. A simple random sampling method was used to select 400 $(\mathrm{n}=400)$ participants consisting of general employees, supervisors, managers, officials and support staff holding permanent, temporary or contract positions. The list of personnel employed in a water utility company was obtained from the human resource department. A random sampling using random table numbers was used to draw sample elements. Of the 400 questionnaires distributed, 250 were completed and returned resulting in a 63 percent response rate. 
Measuring Instrument and Collection of Data: A structured questionnaire was chosen for the study, which consisted of four sections. Section A focused on the demographic profile of the respondents. Section B measured JS. The measurement of JS was adapted from the overall JS scale designed by Breyfield and Rothe (1951). The overall JS scale consisted of five items describing JS. A five-point Likert scale ranging from $1=$ strongly disagree to $5=$ strongly agree was used. Section $C$ was an OC scale. The scale measured the level of OC among employees. The measurement of OC was adopted from the revised commitment scale items designed by Jaros (2007). The scale consisted of 20 items that were designed to measure affective, continuance and normative commitment. Respondents were asked to respond to each item on a five-point Likert scale ranging from $1=$ strongly disagree to $5=$ strongly agree. In Section D, OCB was measured using Jung and Yoon's (2012) OCB scale. The five dimensions in the scale were altruism, conscientiousness, sportsmanship, courtesy and civic virtue. A five-point Likert scale was used ranging from $1=$ strongly disagree to $5=$ strongly agree.

Reliability and Validity: The reliability estimates of the scales were confirmed through Cronbach alpha coefficient $(\alpha)$. The test provided an acceptable indication of the reliability of the research instruments for OC, JS and OCB. The reliability measures for the variables were as follows: JS - 0.927; normative commitment 0.886; $\mathrm{AC}-0.809$; $\mathrm{CC}-0.781$; and OCB - 0.809. All the internal consistency measures were above the recommended threshold of 0.7 (Osborne, 2008). Various forms of validity, face, content, construct, convergent and predictive, were used to measure the validity of the instrument. Content validity was ascertained through seeking advice from academic experts in the field of organisational behaviour to confirm if the items pertaining to the constructs in the questionnaire were covered sufficiently. Construct validity was determined through factor analysis where low factor loadings $(<0.50)$ and cross loading were deleted. In addition, correlation analysis was performed and the results of the analysis confirmed a significant correlation between the constructs, thus verifying construct validity. Convergent validity was examined through the computation of the Pearson correlation coefficient. The correlation among the constructs was strong as shown in Table 3.

\section{Results and Discussion}

Factor Analysis: Exploratory factor analysis (EFA) was performed on OC. Prior to factor analysing the OC scale, a Kaiser-Meyer-Olkin (KMO) measure of sampling adequacy and Bartlett's test were performed on the OC scale to determine whether the data set was suitable for factor analysis (Hinton, McMurray \& Brownlow, 2014). The KMO value for OC scale (0.875), as shown in Table 1, was well above the 0.05 threshold level and validated that the data-set was appropriate to conduct factor-analysis (Mulaik, 2009).

Table 1: KMO and Bartlett's Test of Organisational commitment

\begin{tabular}{lll}
\hline \multicolumn{2}{l}{ Kaiser-Meyer-Olkin Measure of Sampling Adequacy } & $\mathbf{. 8 7 5}$ \\
\hline Bartlett's test of sphericity & Approx. chi-square & 1610.723 \\
& DF & 91 \\
& Sig. & .000 \\
\hline
\end{tabular}

Using EFA with Kaiser Normalisation as shown in Table 2, three factors were extracted with an eigenvalue greater than one (Plonsky, 2015). The table also indicates the percentage of variance and the cumulative percentage of variance for each factor. The cumulative percentage of variance for all three factors was recorded as 64.833 percent. The factors were named as indicated in Table 2.

Table 2: Eigenvalues, Percentage of Variance Explained and Cumulative Percentage of Section C

\begin{tabular}{lllll} 
Component description & No. of items & Eigenvalues & \% of variance & Cumulative \% \\
\hline Factor 1 & 6 & 3.816 & 27.257 & 27.257 \\
Factor 2 & 4 & 2.787 & 19.906 & 47.164 \\
Factor 3 & 4 & 2.474 & 17.669 & 64.833 \\
Factor 1 = Normative commitment & & & \\
Factor 2 = Affective commitment & & & \\
Factor 3= Continuance commitment & & & \\
\hline
\end{tabular}


Correlations: Correlation analysis was performed to establish the intensity of the relationship amongst OC, JS and OCB. Table 3 illustrates that JS was significantly correlated with normative commitment ( $r=.464$; $\mathrm{p}<0.01)$. Job satisfaction also showed a positive significant correlation with affective commitment $(r=.613$; $\mathrm{p}<0.01$ ). A strong correlation between JS and affective commitment was observed. The results of the correlation analysis reflected that OCB had a positive significant correlation with JS $(r=.598 ; \mathrm{p}<0.01)$. Organisational citizenship behaviour had a positive significant correlation with normative commitment $(r=.435 ; \mathrm{p}<0.01)$. Similarly, the affective commitment was positively correlated with OCB $(r=.413 ; \mathrm{p}<0.01)$. AC and NC were positive correlates $(r=.591 ; \mathrm{p}<0.01)$. Finally, very weak correlations were noticed between continuance commitment and OCB $(r=-.067 ; \mathrm{p}<0.01)$ and between continuance commitment and JS $(r=-.095$; $\mathrm{p}<0.01)$.

Table 3: Descriptive Statistics and Correlations for Constructs

\begin{tabular}{|c|c|c|c|c|c|c|c|c|}
\hline \multicolumn{2}{|c|}{ Constructs } & П & SD & 1 & 2 & 3 & 4 & 5 \\
\hline 1. & Normative commitmen & t3.58 & 1.051 & .886 & & & & \\
\hline 2. & Affective commitment & 3.42 & 1.096 & $.591^{* *}$ & .809 & & & \\
\hline 3. & $\begin{array}{l}\text { Continuance } \\
\text { commitment }\end{array}$ & 2.65 & 1.225 & -.086 & -.095 & .781 & & \\
\hline 4. & JS & 3.85 & 0.986 & $.464^{* *}$ & $.613^{* *}$ & -.095 & .927 & \\
\hline 5. & OCB & 4.04 & 0.909 & $.435^{* *}$ & $.413^{* *}$ & -.067 & $.598^{* *}$ & .880 \\
\hline
\end{tabular}

Note: $\mathrm{N}=250$. Estimated reliabilities appear on the diagonal. Constructs 1 to 3 are the factors extracted from OC. OC=organisational commitment; JS=job satisfaction; $\mathrm{OCB}=$ organisational citizenship behaviour. Values on the diagonal in boldface are estimated scale reliability. Correlations were reported significant at the level of 0.01 (2-tailed).

Regression Analysis: The values of the regression analysis are captured in Table 4. Multiple regression analysis was conducted to establish the predictive relationship between OC factors (normative commitment, affective commitment and continuance commitment), JS and OCB. Regression analysis was performed to test whether OC, as an independent variable, predicted dependent variables, JS and OCB. The results of the regression analysis are reported in Table 4.

Table 4: Results of the Regression Analysis

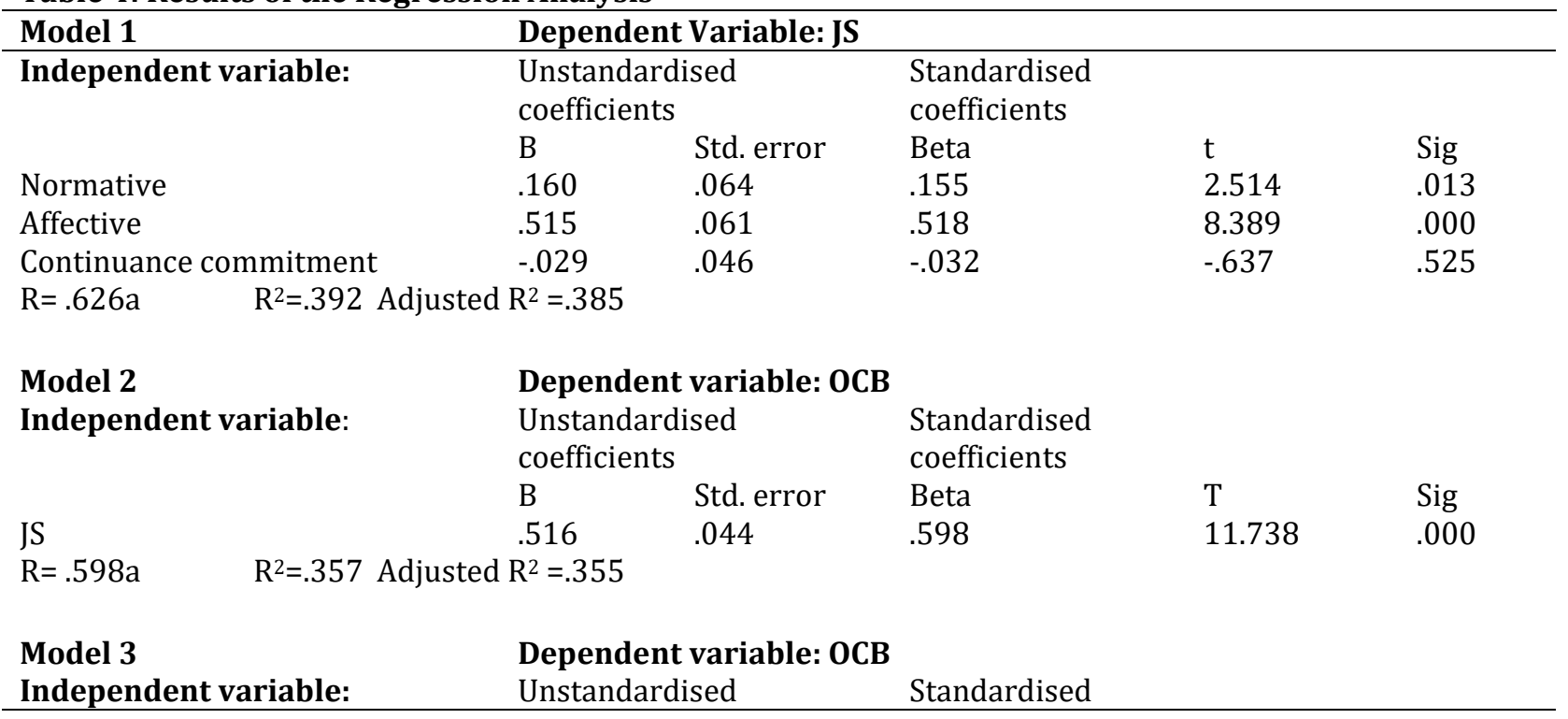




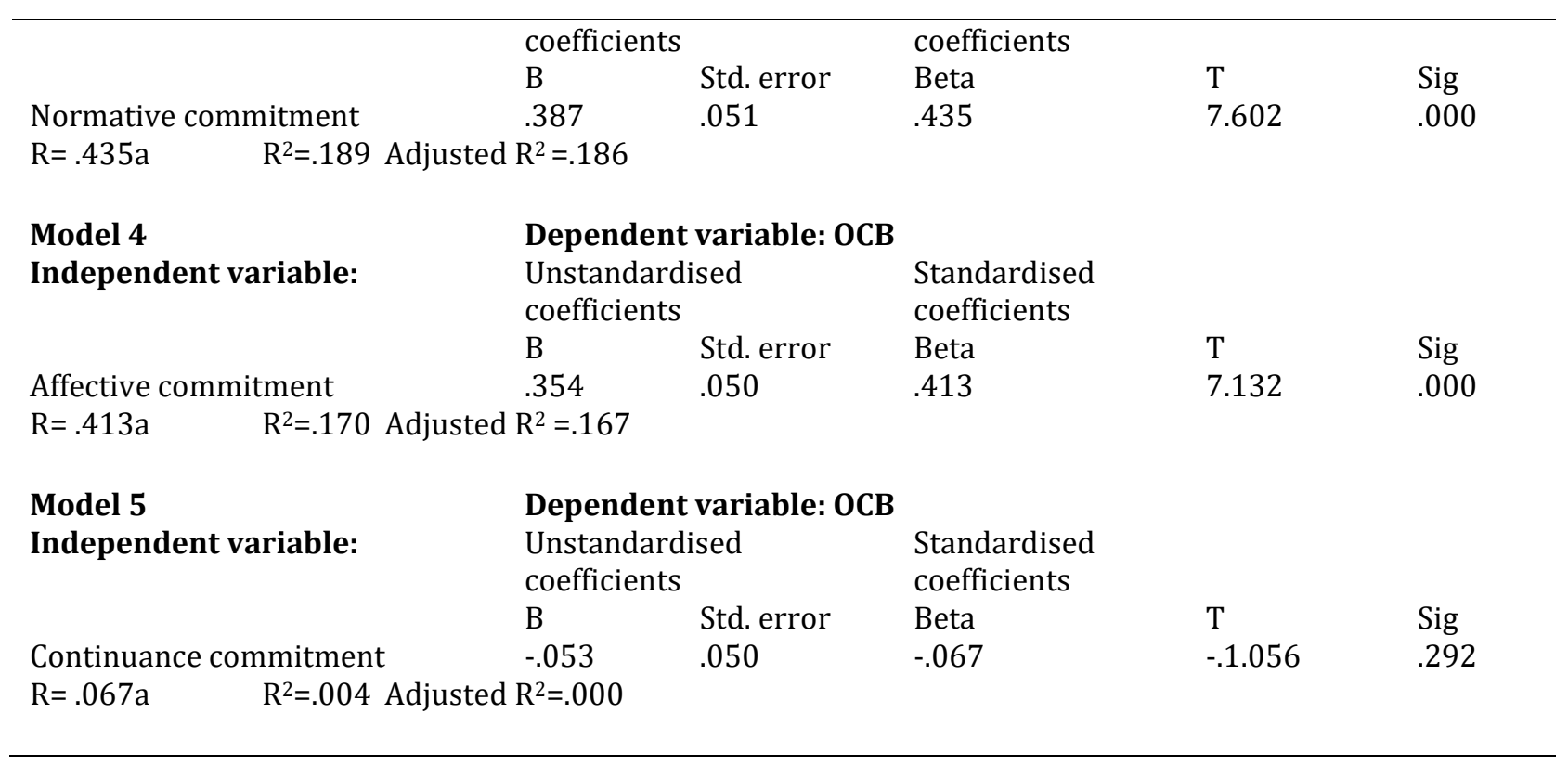

For Model 1 the results of the regression analysis indicated an adjusted $\mathrm{R}^{2}$ of .385. The beta coefficients for the independent variables and the attendant significance level of the predictive relationships were as follows: normative commitment $(\beta=.155 ; \mathrm{p}<0.01), \mathrm{AC}(\beta=.518 ; \mathrm{p}<0.01)$ and $\mathrm{CC}(\beta=.-032 ; \mathrm{p}<0.01)$. In Model 2 , the independent variable in the regression equation was JS and the dependent variable was OCB. Regression analysis results indicated an adjusted $\mathrm{R}^{2}$ of .355 . The beta coefficient for the predictive relationship between JS and OCB was .598 $(\beta=.598 ; p<0.01)$. Model 3 reflects the predictive association of NC (independent variable-IV) on OCB (dependent variable-DV). The result of the regression analysis was a beta coefficient of $.435(\beta=.435 ; p<0.01)$. The adjusted $R^{2}$ of .186 was recorded for the predictive relationship between normative commitment and OCB. In Model 4, the affective commitment was entered as an independent variable, whereas OCB was inserted as the dependent variable. The beta coefficient of affective commitment was .413 $(\beta=.413 ; p<0.01)$. The regression results for the relationship between affective commitment and OCB was an adjusted $\mathrm{R}^{2}$ of .167. Finally, in Model 5, continuance commitment and OCB were independent and dependent variables respectively. The beta coefficient for continuance commitment was $-.067 \quad(\beta=-.067$; $\mathrm{p}<0.01$ ) and the adjusted $\mathrm{R}^{2}$ of .000 was registered for the predictive relationship between continuance commitment and OCB.

Discussion: The results of the predictive association between the three OC factors and JS showed that the three factors of OC collectively contributed 39 percent of the variance in employees' JS. This implied that the factors together contributed 39 percent to the occurrence of JS. Based on the regression results, the normative commitment had no significant effect on JS, which suggested that normative commitment did not predict JS. However, a positive connection was observed between NC and JS. As a result of this finding, the hypothesis: A positive link exists between normative commitment and JS (H1) was supported. A significant positive correlation between JS and normative commitment implies that if employees are satisfied with their jobs they tend to be indebted and morally obliged to remain with the organisation. JS could be influenced by a number of factors such as a supportive work environment, leadership, relationship with co-workers and OC (Lau \& Oger 2012). Should these factors be present, employees will be morally obliged to commit to the wellbeing of the organisation (Yang 2008). The finding on the lack of predictive relationship between JS and normative commitment is supported by the study of Lumley et al. (2011), which confirmed that the relationship between normative commitments with JS is inconsistent and non-existent. Elias (2007) reiterates that the reason for the non-existent relationship is based on the notion that normative commitment relies strongly on factors external to employees' control such as work conditions and social norms rather than psychological attachment and as such, it does not relate to employees' JS. 
Affective commitment contributed positively to the prediction of JS. Based on the finding, the postulated hypothesis that a positive association exists between affective commitment and JS (H2) was supported. Strong correlations between JS and affective commitment indicated that the water utility employees generally express high levels of affective commitment, resulting in high JS. Research has found JS to correlate strongly with AC; in fact, JS is a function of affective commitment (Boles, Madupalli, Rutherford \& Wood, 2007). This view corresponds with Chang's (2015) findings, which reveal that employees' high level of employees' JS renders them willing to identify with, engage in organisational activities and show loyalty to the organisation. There is also substantial evidence that shows that the relationship can also be the other way round in which job characteristics such as salary, relationship with co-workers and the job itself could induce employees with affective commitment to an organisation (Anari, 2012). In another study, Adekola (2012) propounds that employees remain highly committed to their organisation because of factors such as pay, freedom, training and development programmes. There is also empirical evidence that confirms that affective commitment can be improved through improved job characteristics such as autonomy and empowerment (Boles et al., 2007). This finding echoes the assertion of Namasivayam and Zhao (2007) that affective commitment of employees is subject to the adjustment of job characteristics by the organisation. Conversely, continuance commitment was not a predictor of JS and no correlations were observed between the variables, resulting in the rejection of the following hypothetical statement: There is a positive relationship between continuance commitment and JS (H3).

This finding intimates that the water utility employees' level of JS is not in any way influenced by their continuance commitment. These results are congruent with the findings of Kaplan, Ogut, Kaplan and Aksay (2012). The authors opine that employees who have psychologically calculated the costs associated with leaving the organisation may feel imprisoned and ultimately develop negative attitudes towards their job and the organisation. As a result, these employees display low levels of JS (Namasivayam \& Zhao, 2007). This contention is congruent to the previous research, which demonstrates that the lack of predictive relationship between the aforementioned variables could be attributed to the feeling of entrapment experienced by employees, which results in a negative attitude towards the organisation and their work. Implicit in the finding on the relationship between JS and OCB was that job satisfaction contributed 36 percent to the prediction of OCB, which firmly confirms that OCB occurs as a result of JS. The result was indicative of the predictive relationship between JS and OCB; hence, the hypothesis: Job satisfaction is positively associated with OCB (H4), was accepted. Compared with the findings of the predictive association between AC and OCB, the higher beta coefficient of JS relationship with OCB suggests that JS played a significant mediating role between affective commitment and OCB. The finding in respect of the relationship between JS and OCB is confirmed by previous studies, which seem to suggest that employees with a high level of JS tend to engage in extra-role behaviours such as helping others, generating innovative solutions to help the organisation achieve its goals and adhering to rules and procedures (Cohen \& Keren, 2008; Modassir \& Singh, 2008; Alizadeh et al., 2012). It is vivid from the data that normative commitment contributed 18 percent to the prediction of OCB, thereby indubitably confirming that normative commitment contributed to the incidence of OCB. Thus the hypothesis normative commitment and OCB are positive correlates (H5) was supported.

OCBs predictive relationship, as indicated, concurs with other studies, which propound that employee who show high levels of normative commitment exhibit high levels of OCB (Zayas-Ortiz, Rosario, Marquez \& Gruñeiro, 2015). Additionally, the study by Meyer and Parfyonova (2010) reveals that moral imperative influences employees to pursue organisational citizenship behaviours because of their conviction that it is a morally right to do so. A predictive relationship between normative commitment and OCB affirmed that the occurrence of OCB in the water utility company was a sequel of the employees' moral obligation to remain with the organisation. Namasivayam and Zhao (2007) are of the view that when employees have positive social experiences at work and are offered advancement opportunities they feel morally bound to reciprocate by retaining membership of an organisation. Tojari, Esmaeilli and Majedi (2013) add that positive feeling about social experiences and advancement opportunities are a moral inspiration for employees to exert effort beyond the job requirements in pursuance of the attainment of an organisation's interests and goals. Model 4 indicated a 17 percent predictive nature of the relationship between $\mathrm{AC}$ and OCB. The results were central to validating the hypothetical statement: there is an existence of a positive association between AC and OCB (H6). 
A similar view is expressed by Ibrahim and Aslinda (2013) that an emotional connection between individuals created with the employing organisation generates the desire to display OCB. In this regard, Fatimah, Amiraa and Halim (2011) amplify that committed employees sacrifice their personal interests, espouse discretionary behaviours that exceed in-role requirements of the job, thus leading to the organisation's effectiveness. In the final analysis, no correlations were observed between continuance commitment and OCB and the predictive relationship between continuance commitment and OCB was equally non-existent, with continuance commitment contributing absolutely nothing to the prediction of OCB. Therefore, the hypothetical statement: hypothesis: CC is positively related to OCB (H7), was rejected. A weak correlation between continuance commitment and OCB attested that employees' OCB was not influenced by the fear of losing investment they have made to the organisation or vice versa. It is not surprising that the finding of Özdem (2012:58) established that employees who displayed high continuance commitment did not have the best interest of the organisation at heart and were not loyal to the organisation compared to affectively committed employees. This finding is congruent to the findings of Khan, Naseem and Masood (2016) who found that continuance commitment was not associated with desired work behaviours, such as OCB, job performance and reduced absenteeism. Other studies (Wang, 2008; Hur, Park \& Kim, 2010) refer to this form of commitment as passive commitment, an indication that employees stay with an organisation because they have no alternative job.

\section{Implications, limitations of the Study, Future Research and Recommendations}

Theoretical Implication: Previous studies explored the nature of OCB and its impact on organisational performance. To cite a few, Cohen and Keren (2008); Mishra, Mishra, Kumar (2010) and Runhaar, Konermann \& Sanders (2013) contributed to the OCB literature. Earlier research has also advanced the importance of the relationship between OC and JS or OC and JS (Noor 2009; Mohammad, Habib \& Alias 2011; Zeinabadi \& Salehi, 2011). This study enhanced insight to the relationship by highlighting the significance of the predictive relationship of both JS and OC with OCB. Thus, employees' willingness to exhibit OCB is attributed directly to the strong presence of employees' JS, normative commitment, affective commitment and continuance commitment. This study expanded the information on OCB by providing insight on the theory that underpins $\mathrm{OCB}$, to demonstrate how employees progress to display OCB and its contributing nature to an organisation's effectiveness. The level of display of OCB varies on the type of the precursor.

Implicit is that JS, normative commitment, affective commitment and continuance commitment have varying levels of correlational and regressive association with OCB. JS emerged as a significant variable that induced the enactment of OCB. Furthermore, the study also confirms and expands the knowledge of OC by providing the literature that supports $\mathrm{OC}$ as a multi-dimensional construct. Continuance, affective and normative commitments have provided a context for the deeper understanding of the construct. Subsequent to a thorough review of the literature on the three-component model of $\mathrm{OC}$ and analysis of data collected from a water utility company, the affective commitment was found to be a great source for the display of OCB. Over and above, OC occurred to influence a wide range of organisation-relevant results, like organisational efficiency, low staff resignation, employee-satisfaction and return on investment (Morrow 2011). If employees realise that management recognises and rewards their efforts, they would develop an emotional attachment and desire to maintain a long-term relationship with the organisation, thus triggering the display of OCBs.

Limitations of the Study: As with most field research, this study had several limitations that should be taken into consideration when interpreting the results. First, the study was limited in that it was undertaken among employees of a water utility company in Gauteng province only. The study could not be generalised to other provinces. Secondly, this study was limited in scope in that there might have been other factors that could also have had a mediating role on the effect of JS and OC on OCB. Thirdly, data collection relied on data provided voluntarily by the respondents, who could have been biased in completing the questionnaire. Finally, of the 400 questionnaires issued, only 250 were completed and returned, thus limiting the size of the sample. A larger sample size of 400 might have yielded somewhat different results.

Future Research: The present study aimed to investigate the impact of OC and JS on OCB at a water utility company in Gauteng. The scope of this study could be extended to other provinces in order to examine 
similarities and differences in various sites of delivery across the country. This could also maximise the full participation of employees in the entire organisation and yield better results for generalisation. To enhance insight into $O C$ and OCB, a comprehensive study could be undertaken to explore the mediating role of organisational support and distributive justice on the relationship between OC and OCB. This study could be conducted in private or public entities. The value of demographic characteristics, such as employees' level of education, gender, age, marital status race length of service, employment status and position held was not explored in this study. It is possible that a comprehensive examination of these characteristics could offer additional insight to the knowledge of JS, OC and OCB. Thus, future studies need to investigate the relationship between demographic characteristics of employees with JS, OC and OCB.

\section{Conclusion}

In summary, regression analysis revealed significant predictive relationships between affective commitment and JS; JS and OCB: normative commitment and OCB; affective commitment and OCB. Moreover, it can be concluded that the more employees are committed affectively to the organisation, the greater they will express high JS. Equally so, the more satisfied employees are with their jobs, the more likely they will exhibit citizenship related behaviours and the more the organisation will benefit. In the same manner, the higher the employees' sense of internalised obligation and affective commitment, the more they will be willing to display organisational citizenship behaviours.

Recommendations: In relation to the finding pertaining to the relationship between JS and OCB, management should consider improving human resources management processes such as supervision, skill variety, pay and job autonomy to ensure that employees find enjoyment in their jobs, which could lead to the development of OCBs. This finding is in concordance with the works of Chen and Johantgen (2010); Cohen and Keren (2008), which found that employees who are happy with some aspects of their job (job characteristics) are more likely to display high levels of JS and are inclined to partake in extra-role behaviours that benefit the organisation. Management could further engage in job enrichment activities to provide employees with the opportunity to decide how their jobs should be performed. Job enrichment generates JS, which could engender employee willingness to enact extra-role behaviours. In a similar vein, job-fit could be implemented in order to strike a balance between employees' skills and abilities with the requirements of the job. The relationship between OC and OCB could be improved by introducing performance-related pay to reward employees. Additionally, involving employees in decision-making processes cultivates higher levels of continuance commitment, which encourages employees to perform extra-role activities that support the attainment of organisational goals. Managers who encourage employees to participate in decision-making processes foster $\mathrm{OC}$ among employees and encourage them to go beyond the formal requirements of the job (OCB), to achieve organisational goals.

\section{References}

Adekola, B. (2012). The impact of organizational commitment on job satisfaction: a study of employees at Nigerian universities. International Journal of Human Resource Studies, 2(2), 1-17.

Alimohammadi, M. \& Neyshabor, A. J. (2013). Work motivation and organisational commitment among Iranian employees. International Journal of Research in Organisational Behaviour and Human Resource Management, 1(3), 1-12.

Alizadeh, Z., Darvishi, S., Nazari, K. \& Emami, M. (2012). Antecedents and consequences of organisational citizenship behaviour (OCB). Interdisciplinary Journal of Contemporary Research in Business, 3(9), 494-505.

Altinoz, M., Cakiroglu, D. \& Cop, S. (2012). The effect of job satisfaction of the talented employees on organisational commitment: a field of research. Social and Behavioural Sciences Journal, 58, 322-330.

Anari, N. (2012). Teachers: emotional intelligence, job satisfaction, and organizational commitment. Journal of Workplace Learning, 24(4), 256-269.

Anis, A., Khan, M. A. \& Humayoun, A. A. (2011). Impact of organizational commitment on job satisfaction and employee retention in pharmaceutical industry. African Journal of Business Management, 5(17), 7316-7324. 
Aziri, B. (2011). Job satisfaction: a literature review. Management Research and Practice, 3(4), 77-86.

Bateman, T. S. \& Organ, D. W. (1983). Job Satisfaction and the good soldier: The relationship between affect and employee "citizenship. The Academy of Management Journal, 26(4), 587-595.

Boles, J., Madupalli, R., Rutherford, B. \& Wood, J. A. (2007). The relationship of facets of salesperson job satisfaction with affective organisational commitment. Journal of Business \& Industrial Marketing, 22(5), 311-321, DOI: 10.1108/08858620710773440.

Breyfield, A. \& Rothe, H. (1951). An index of job satisfaction. Journal of Applied Psychology, 35,307-311.

Çalişkan, E. N. (2010). The impact of strategic human resource management on organizational performance. Journal of Naval Science and Engineering, 6(2), 100-116.

Chang, C. (2015). Moderating effects of nurses' organizational support on the relationship between job satisfaction and organizational commitment. Western Journal of Nursing Research, 37(6), 724-745.

Chen, Y. M. \& Johantgen, M. E. (2010). Magnet hospital attribute in European hospitals: a multilevel model of job satisfaction. International Journal of Nursing Studies, 47, 1001-1012.

Chinomona, R. (2012). The impact of organisational support on work spirituality, organizational citizenship behaviour and job performance: the case of Zimbabwe's small and medium enterprises (SME) sector. African Journal of Business Management, 6(36), 10003-10014.

Cohen, A. \& Keren, D. (2008). Individual values and social exchange variables: examining their relationship to and mutual effect on in-role performance and organisational citizenship behaviour. Group and Organisation Management, 33(4), 425-452.

Dash, S. \& Pradhan, R. K. (2014). Determinants and consequences of organisational citizenship behaviour: A theoretical framework for Indian manufacturing organisations. International Journal of Business and Management Invention, 3(1), 17-27.

Davoudi, S. M. M. (2012). A comprehensive study of organisational citizenship behaviour (OCB): introducing the term, clarifying its consequences and identifying its antecedents. Arth Prabandh: A Journal of Economics and Management (APJEM), 1(2), 73-85.

Dirani, K. M. \& Kuchinke, K. P. (2011). Job satisfaction and organisational commitment: validating the Arabic Satisfaction and Commitment Questionnaire (ASCQ), testing the correlations, and investigating the effects of demographic variables in the Lebanese banking sector. The International Journal of Human Resource Management, 22(05), 1180-1202. DOI: 10.1080/09585190801993901

Dugguh, S. \& Dennis, A. (2014). Job satisfaction theories: Traceability to employee performance in organisations. Journal of Business and Management (IOSR-JBM), 16(5), 11-18.

Elias, S. M. (2007). Employee commitment in times of change: assessing the importance of attitudes toward organisational change. Journal of Management, 20(10), 1-19, DOI: 10.1177/0149206307308910.

Falkensburg, K. \& Schyns, B. (2007). Work satisfaction, organisational commitment and withdrawal behaviours. Management Research News, 30(10), 708-723.

Fatimah, 0, Amiraa, A. M. \& Halim, F. W. (2011). The relationships between organizational justice, organizational citizenship behaviour and job satisfaction. Pertanika Journal for Social Science and Humanities, 19(5), 115-121.

Goetz, K., Campbell, S. M., Broge, B., Dörfer, C. E., Brodowski, M. \& Szecsenyi, J. (2012). The impact of intrinsic and extrinsic factors on the job satisfaction of dentists. Community dentistry and oral epidemiology, 40(5), 474-480.

Güleryüz, G., Güney, S., Aydin, E. M. \& Aşan, O. (2008). The mediating effect of job satisfaction between emotional intelligence and organisational commitment of nurses: a questionnaire survey. International Journal of Nursing Studies, 45, 1625-1635.

Gunlu, E., Aksarayli, M. \& Sahin Perçin, N. (2010). Job satisfaction and organizational commitment of hotel managers in Turkey. International Journal of Contemporary Hospitality Management, 22(5), 693-717.

Herzberg, F. M. \& Snyderman, B. (1959). The motivation to work, 2, li.

Hettiararchchi, H. A. H. \& Jayarathna, S. M. D. Y. (2014). The effect of employee work-related attitudes on employee job performance: a study of tertiary and vocational education sector in Sri Lanka. IOSR Journal of Business and Management (IOSR-JBM), 16(4), 74-83.

Hinton, P. R., McMurray, I. \& Brownlow, C. (2014). SPSS Explained (2nd ed), New York: Routledge.

Hur, W., Park, J. \& Kim, M. (2010). The role of commitment on the customer benefits-loyalty relationship in mobile service industry. The Service Industries Journal, 30(14), 2293-2309, DOI: 10.1080/02642060802629877. 
Ibrahim, M. A. \& Aslinda, A. (2013). Relationship between organisational commitment and organisational citizenship behaviour (OCB) at government-owned corporation companies. Journal of Public Administration and Governance, 3(3), 35-42.

Jaros, S. (2007). Meyer and Allen model of organisational commitment: measurement issues. The Institute of Chartered Financial Analysts of India Journal of Organisational Behaviour, 6(4), 1-25.

Jung, H. S. \& Yoon, H. H. (2012). The effects of emotional intelligence on counterproductive work behaviours and organisational citizen behaviours among food and beverage employees in a deluxe hotel. International Journal of Hospitality Management, 31(2), 369-378.

Kaplan, M., Ogut, E., Kaplan, A. \& Aksay, K. (2012). The relationship between job satisfaction and organisational commitment: the case of hospital employees. World Journal of Management, 4(1), 2229.

Kargar, M. (2012). Evaluation of organisational commitment of employees in university; case study: Islamic Azad University. Journal of Basic and Applied Scientific Research, 2(5), 5017-5021.

Kasemsap, K. (2013). Strategic human resource practice: a functional framework and causal model of leadership behaviour, job satisfaction, organisational commitment and job performance. Journal of Social and Development Sciences, 4(5), 198-204.

Khan, R., Naseem, A. \& Masood, S. A. (2016). Effect of continuance commitment and organizational cynicism on employee satisfaction in engineering organizations. International Journal of Innovation, Management and Technology, 7(4), 141-146.

Khan, S. D., Nawaz, A. \& Jan, F. A. (2012). Impact of demographic diversities on the job satisfaction and its consequences: case of academicians in higher learning institutions of Pakistan (application of stepwise multiple regression). Global Journal of Management and Business Research, 12(19), 34-43.

Lau, C. M. \& Oger, B. (2012). Behavioural effects of fairness in performance measurement and evaluation systems: empirical evidence from France. Advances in Accounting, incorporating Advances in International Accounting, 28, 323-332.

Liu, C., Li, Q. \& Zhao X. (2009). Challenges and opportunities in collaborative business process management: overview of recent advances and introduction to the special issue. Information Systems Frontiers. 11, 201-209, DOI 10.1007/s10796-008-9089-0.

Lo, M. C. \& Ramayah, T. (2009). Dimensionality of organizational citizenship behaviour (OCB) in a multicultural society: the case of Malaysia. International Business Research, 2(1), 48-55.

Lumley, E. J., Coetzee, M., Tladinyane, R. \& Ferreira, N. (2011). Exploring the job satisfaction and organisational commitment of employees in the information technology environment. Southern African Business Review, 15(1), 100-118.

Mamman, A., Kamoche, K. \& Bakuwa, R. (2011). Diversity, organisational commitment and organisational citizenship behaviour: an organising framework. Human Resource Management Review, 22, 285-302.

Meyer, J. P. \& Allen, N. J. (1991). A three-component conceptualization of organisational commitment. Human Resource Management Review, 1(1), 61-89.

Meyer, J. P. \& Parfyonova, N. M. (2010). Normative commitment in the workplace: a theoretical analysis and re-conceptualization. Human Resource Management Review, 20, 283-294.

Mishra, S. K., Mishra, B. \& Kumar, P. (2010). Traditional attitudinal variables matters for organisational citizenship behaviour among middle-level managers. Journal of the Indian Academy of Applied Psychology, 36(2), 255-261.

Modassir, A. \& Singh, T. (2008). Relationship of emotional intelligence with transformational leadership and organisational citizenship behaviour. International Journal of Leadership Studies, 4(1), 3-21.

Mohammad, J., Habib, F. Q. \& Alias, M. A. (2011). Job satisfaction and organisational citizenship behaviour: an empirical study at higher learning institutions. Asian Academy of Management Journal, 16(2), 149165.

Morris, M. G. \& Venkatesh, V. (2010). Job characteristics and job satisfaction: Understanding the role of enterprise resource planning system implementation. MIS Quarterly 34(1), 143-161.

Morrow, P. P. (2011). Managing organisational commitment: insights from longitudinal research. Journal of Vocational Behaviour, 79, 18-35.

Mulaik, S. A. (2009). Foundations of factor analysis. 2nd ed. Boca Raton: Tailor \& Francis Group, LLC. 
Nadiri, H. \& Tanova, C. (2010). An investigation of the role of justice in turnover intentions, job satisfaction, and organisational citizenship behaviour in hospitality industry. International Journal of Hospitality Management, 29, 33-41.

Namasivayam, K. \& Zhao, X. (2007). An investigation of the moderating effects of organisational commitment on the relationships between work-family conflict and job satisfaction among hospitality employees in India. Tourism Management, 28, 1212-1223.

Neininger, A., Lehmann-Willenbrock, N., Kauffeld, S. \& Henschel, A. (2010). Effects of team and organizational commitment-a longitudinal study. Journal of Vocational Behaviour, 76, 567-579.

Nematian, M., Zadeh, M. R. \& Chehrazi, B. (2015). Effectiveness of organisational commitment and organisational learning of the official staff of human resource management of National Iranian organisational citizenship behavior on south oil company. Indian Journal of Fundamental and Applied Life Sciences, 5(S4), 378-388.

Ng, T. W. H. \& Feldman, D. C. (2011). Affective organisational commitment and citizenship behaviour: linear and non-linear moderating effects of organisational tenure. Journal of Vocational Behaviour, 79, 528537.

Nielsen, T. M., Bachrach, D. G., Sundstrom, E. \& Halfhill, T. R. (2012). Utility of OCB: organisational citizenship behaviour and group performance in a resource allocation framework. Journal of Management, 38(2), 668-694.

Noor, A. (2009). Examining organisational citizenship behaviour as the outcome of organisational commitment: a study of university teachers of Pakistan. Proceedings $2^{\text {nd }}$ China Banking Regulatory Commission. Pakistan: Army Public College of Management Sciences (APCOMS).

Organ, D. W. (1988). Organizational citizenship behavior: the good soldier syndrome. Lexington, MA: Lexington Books.

Organ, D. W. (1997). Organizational citizenship behavior: it's construct clean-up time. Human Performance, 10, 85-97.

Organ, D. W. \& Ryan, K. (1995). A meta-analytic review of attitudinal and dispositional predictors of organizational citizenship behavior. Personnel Psychology, 48, 775-802.

Osborne, J. (2008). Best practices in quantitative methods. California: Sage Publications.

Özdem, G. (2012). The relationship between the organisational citizenship behaviours and the organisational and professional commitments of secondary school teachers. Journal of Global Strategic Management, $12,47-64$.

Paré, G. \& Tremblay, M. (2007). The influence of high-involvement human resources practices, procedural justice, organisational commitment, and citizenship behaviours on information technology professionals' turnover intentions. Group \& Organisation Management, 32(3), 326-357.

Plonsky, L. (2015). Advancing quantitative methods in second language research. New York: Routledge Taylor \& Francis Group.

Podsakoff, P. M., MacKenzie, S. B. \& Organ, D. W. (2006). Organizational citizenship behavior: its nature, antecedents, and consequences. Thousand Oaks: SAGE Publications.

Podsakoff, P. M., MacKenzie, S. B., Paine, J. B. \& Bachrach, D. G. (2000). Organizational citizenship behaviors: a critical review of the theoretical and empirical literature and suggestions for future research. Journal of Management, 26(3), 513-563.

Rasheed, A., Jehanzeb, K. \& Rasheed, M. F. (2013). An investigation of the antecedents of organizational citizenship behaviour: case of Saudi Arabia. International Journal of Psychological Studies, 5(1), 128138.

Raza, M. Y., Akhtar, M. W., Husnain, M. \& Akhtar, M. S. (2015). The impact of intrinsic motivation on employee's job satisfaction. Management and organizational studies, 2(3), 80-88.

Runhaar, P., Konermann, J. \& Sanders, K. (2013). Teachers' organisational citizenship behaviour: considering the roles of their work engagement, autonomy and leader-member exchange. Teaching and Teacher Education Journal, 30, 99-108.

Sattar, A., Nawaz, A. \& Khan, S. (2012). The contextual impacts on job satisfaction of employees in the developing states like Pakistan. Universal Journal of Education and General Studies, 1(5), 136-145.

Sayğan, F. N. (2011). Relationship between affective commitment and organisational silence: a conceptual discussion. International Journal of Social Sciences and Humanity Studies, 3(2), 219-227. 
Singh, A. K. \& Singh. A. P. (2009). Does personality predict organisational citizenship behaviour among managerial personnel? Journal of the Indian Academy of Applied Psychology, 35(2), 291-298.

Sun, L., Chow, I. H. S., Chiu, R. K. \& Pan, W. (2013). Outcome favourability in the link between leader-member exchange and organisational citizenship behaviour: procedural fairness climate matters. Leadership Quarterly Journal, 24, 215-226.

Suresh, S. \& Venkatammal, O. (2010). Antecedents of organizational citizenship behaviour. Journal of the Indian Academy of Applied Psychology, 36(2), 276-286.

Tambe, S. \& Shanker, M. (2014). A study of organisational citizenship behaviour (OCB) and its dimensions: a literature review. International Research Journal of Business and Management IRJBM, 1, 67-73.

Tojari, F., Esmaeilli, M. R. \& Majedi, N. (2013). The predictability of coaching efficacy on organisational commitment. European Journal of Experimental Biology, 3(6), 164-171.

Ünal, Ö. F. (2013). Relationship between the facets of job satisfaction and the dimensions of organisational citizenship behaviour: mediating role of organisational commitment. Journal of Faculty of Economics and Administrative Science, 18(1), 243-269.

Wang, Y. (2008). Emotional bonds with supervisor and co-workers: relationship to organizational commitment in China's foreign-invested companies, The International Journal of Human Resource Management, 19(5), 916-931,

Waqas, A., Bashir, U., Sattar, M. F., Abdullah, H. M., Hussain, I., Anjum, W., Ali, M. A. \& Arshad, R. (2014). Factors influencing job satisfaction and its impact on job loyalty. International Journal of Learning \& Development, 4(2), 141-161.

Yahaya, A., Boon, Y., Ramli, J., Baharudin, N. A., Yahaya, N., Ismail, J. \& Shariff, Z. (2011). The implications of organisational citizenship behaviour (OCB) towards the dimensions of learning organisation (LO) in organisations in Southern Malaysia. African Journal of Business Management, 5(14), 5724-5737.

Yang, J. (2008). Effect of newcomer socialisation on organisational commitment, job satisfaction, and turnover intention in the hotel industry. The Service Industries Journal, 28(4), 429-443, DOI: 10.1080/02642060801917430.

Zayas-Ortiz, M., Rosario, E., Marquez, E. \& Gruñeiro, P. C. (2015). Relationship between organisational commitments and organisational citizenship behaviour in a sample of private banking employees. International Journal of Sociology and Social Policy, 35(1), 91-106.

Zeinabadi, H. \& Salehi, K. (2011). Role of procedural justice, trust, job satisfaction, organisational commitment in organisational citizenship Behaviour (OCB) of teachers: proposing a modified social exchange model. Social and Behavioural Sciences, 29, 1472-1481. 